
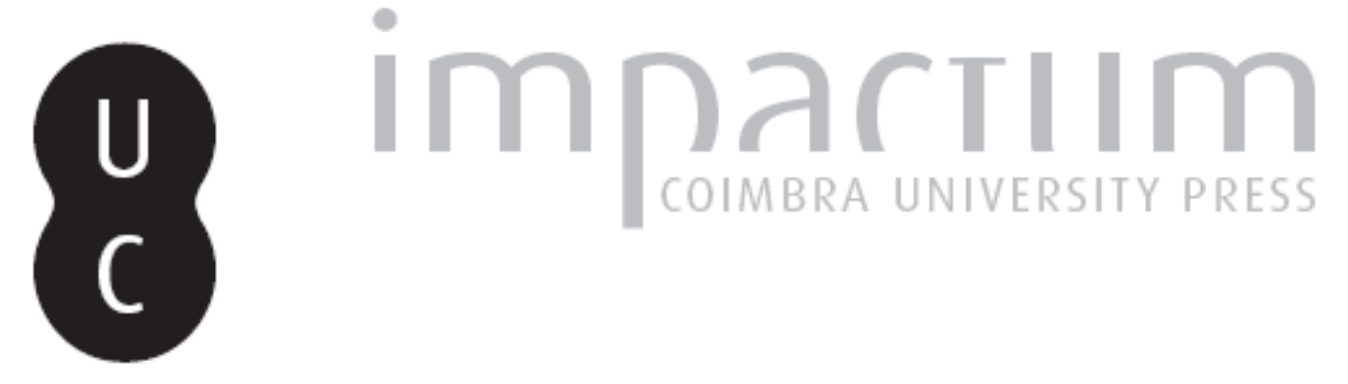

\title{
Beyond “complete urbanization:” uncertainty, the new 'Urban-Rural Connectivity', and the Garden City Model
}

\author{
Autor(es): Kress, Celina
}

Publicado por: Editorial do Departamento de Arquitetura

URL

persistente:

URI:http://hdl.handle.net/10316.2/41196

DOI:

DOI:https://doi.org/10.14195/1647-8681_7_6

Accessed : $\quad$ 26-Apr-2023 12:52:59

A navegação consulta e descarregamento dos títulos inseridos nas Bibliotecas Digitais UC Digitalis, UC Pombalina e UC Impactum, pressupõem a aceitação plena e sem reservas dos Termos e Condições de Uso destas Bibliotecas Digitais, disponíveis em https://digitalis.uc.pt/pt-pt/termos.

Conforme exposto nos referidos Termos e Condições de Uso, o descarregamento de títulos de acesso restrito requer uma licença válida de autorização devendo o utilizador aceder ao(s) documento(s) a partir de um endereço de IP da instituição detentora da supramencionada licença.

Ao utilizador é apenas permitido o descarregamento para uso pessoal, pelo que o emprego do(s) título(s) descarregado(s) para outro fim, designadamente comercial, carece de autorização do respetivo autor ou editor da obra.

Na medida em que todas as obras da UC Digitalis se encontram protegidas pelo Código do Direito de Autor e Direitos Conexos e demais legislação aplicável, toda a cópia, parcial ou total, deste documento, nos casos em que é legalmente admitida, deverá conter ou fazer-se acompanhar por este aviso.

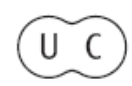




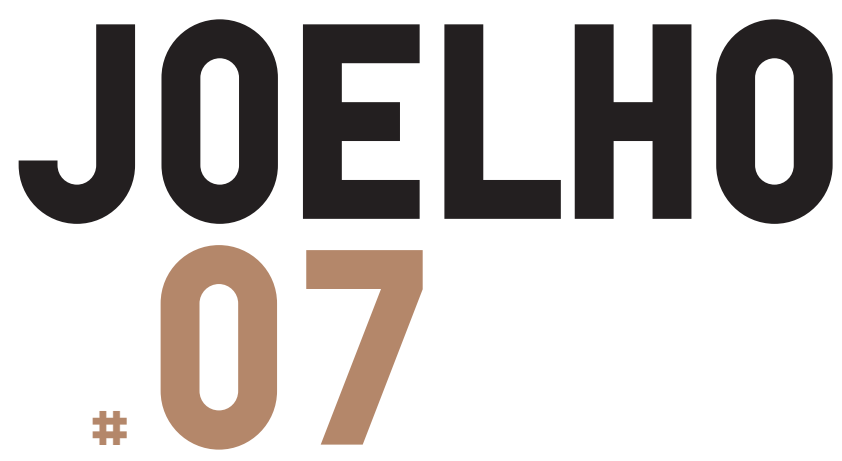

\section{LEARNING FROM MODERN UTOPIAS}

Guest Editors:

Armando Rabaça

Carlos Martins

Tim Verlaan

Hans Ibelings

Caroline Constant

Alexander Eisenschmidt

Carola Hein

Celina Kress

Alessandro Porotto

César Losada Romero

Cecilia Bischeri

and Silvia Micheli

Manfredo Manfredini and Anh-Dung Ta

Exbibition

History of Portuguese

Architecture 


\section{Celina Kress}

Dr.-Ing.,

Center for Metropolitan Studies,

Beyond "Complete Urbanization:"

[1]

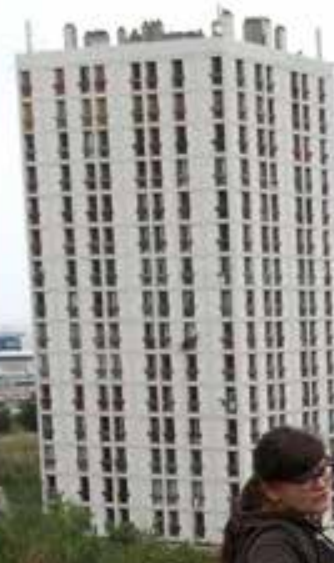


Marxist philosopher Henri Lefebvre's hypothesis of a "society that results from a process of complete urbanization," (Lefebvre, 2003, p. 1) was first published in 1970. Lefebvre insisted on the advent of an "urban society," and he forecasted the "complete subordination of the rural to the urban." At the time this expressed revolutionary thinking and protest against modernist planning ideas, represented by the Athens's Charter functional city principles or the related concept of the 'urban landscape' (Stadtlandschaft). Lefebvre was not the only one campaigning for the revaluation of the inherited city. The American journalist and urban activist Jane Jacobs was another influential agent of the urban. Her seminal book The Death and Life of Great American Cities already in 1961 had delivered a harsh critique of the "verities of orthodox modern city planning and architectural design" (Jacobs, 1961, p. 17), and aggressively attacked Ebenezer Howard's Garden Cities of To-morrow (1902). ${ }^{1}$ In 1970 she further went in line with Lefebvre when arguing for a new and reverse understanding of the priority of cities in early human history: "Cities First - Rural Development Later" Jacobs entitled the first chapter of her second book (Jacobs, 1969) which appeared simultaneously with Lefebvres favouritism of the urban (figs. 1, 2). ${ }^{2}$ This united campaigning in favour of the city led to a sharp polarization of the urban and the non-urban space. Subsequently we tend to generally place the city in the centre while at the same time devalorising sub-urban or rural areas. Actually, cities and their regions as well as rural areas are both affected and connected by new developments, such as: demographic changes, gentrification processes, technical innovation, changing values and lifestyles, fiscal problems, climate change and energy crisis. Against this background it is important to newly conceive and create a space of equal encounter, exchange, and co-operation of the urban and the rural. There is the thesis that modern utopias, as the Garden City model, could offer helpful advices and tools towards this aim.

This article traces back the historic and theoretic origins of the prevailing urban-rural divide in the planning disciplines, the antiurban bias in modern planning approaches and the revaluation of the city since the 1960 s. In the early 21 st century the consciousness of uncertainty became prevalent paving the way for more relational, open approaches aiming at shaping and conceptualizing the new UrbanRural Connectivity. Concluding, the paper rejudges the supposedly well known concept of the Garden City and re-evaluates its potential to equally conceptualise the urban and the rural in planning theory and practice.

\section{The Anti-Urban Bias in the Path of Modernist Planning Ideas}

During the formation phase of the discipline in the nineteenth until the beginning of the twentieth century, aspects of 'the rural' and 'the urban' were both taken into account. A strongly 'anti-urban' doctrine only developed after the First World War.

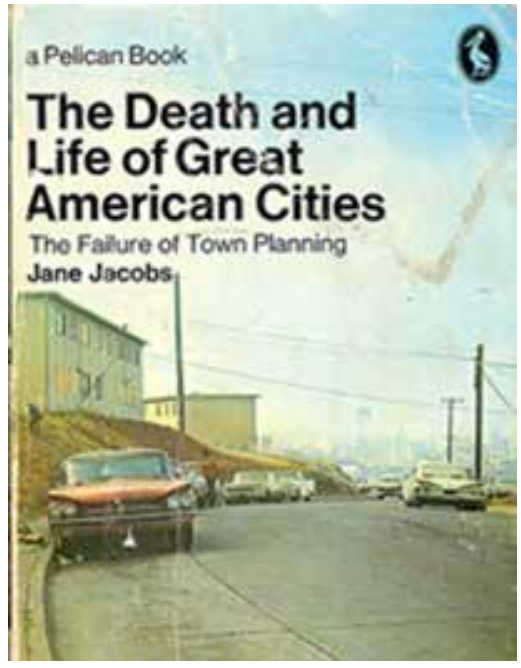

Fig.1 Jane Jacobs (1961), Death and Life of Great American Cities, Pelican Book Cover.

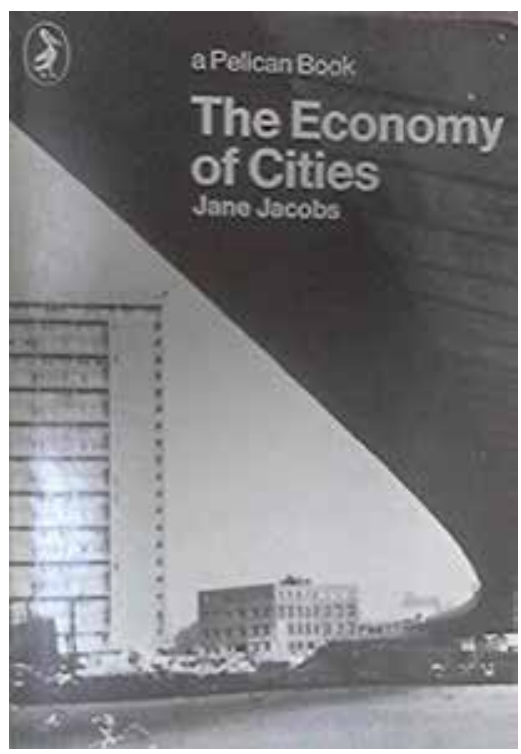

Fig. 2 Jane Jacobs (1969), The Economy of Cities, Pelican Book Cover.

Frontispiece (Fig. 10) Marseille nord, GR_2013. Grande Randonée walking tour testing uncertain spaces. From Foto: BEST Berlin, 2014. 
Urbanization processes of the nineteenth century are characterized by simultaneous push-and-pull dynamics between town and country. Accelerated economic, social, and cultural exchange produced new ways of mixture and overlap, as well as specific cooperation models. These dynamics resulted in ambivalent valuations of both spheres. While the city was hailed for economic power and liberation prospects it was as well damned for its manifold burdens and defects. On the other hand, the country was blamed for traditional torpor and lack of prospects as it was blessed for primary contact, familiarity and integration of labor. ${ }^{3}$ These reverse patterns of devaluation and revaluation found their most obvious physical expression at the urban edges. These 'zones of arrival' were the most dynamic spaces in terms of material and structural formation, social heterogeneity and manifold forms of mutual exchange and bidirectional mobility between the city and the countryside.

The perception and the importance of exchange and cooperation of both spheres - town and country or city and region - are also mirrored at the professional level of the experts. However, regarding town and country, city and region, actors set different priorities as for fields of social and spatial analysis and aims for town planning:

1. The 'urbanists'

The agents of this perspective saw the economic, socio-political, cultural and visual new potentials of the urban as central in their work. They focused on the new living conditions and scrutinized its influence on the behavior of the people. With varying methods they discussed the vibrant, innovative, and creative power of the cities. Around 1900, among this group were to be mentioned the urban sociologist Georg Simmel, the economist Karl Marx, the architect and philosopher August Endell, and the architect and urban theorist Camillo Sitte.

2. The 'urban-regionalists,' or 'urban-ruralists'

The representatives of this perspective, however, observed cities in relation to landscapes and regions. Their opinion was that the burdens and problems of the growing cities could be solved by appropriate exchange with the qualities of the rural. Among this group can be counted the biologist Sir Patrick Geddes, the anarchist Peter Alexander Kropotkin, and the urban theorist and activist Ebenezer Howard. His model of the Garden City - firstly published in 1898 under the title To-Morrow. A Peaceful Path to Real Reform became most influential in urban planning during the 20th century. To date it has been understood as the representative of modernist decentralist and anti-urban planning ideas. This was a severe misunderstanding: Howard's vision lacks any spatial and formal determination. Indeed it is a reflection on economic, functional and social interaction of actors in urban development processes and a proposal for an open spatial arrangement that integrates urban and rural areas. ${ }^{4}$ The driving force of the garden city idea and activism was empathy and compassion for the plight of the poor (urban and rural) and the positive mission to lift and remove the 
burdens of the nineteenth-century city for all its inhabitants. As Peter Hall (1988, p. 7) particularly stressed, Ebenezer Howard's model was rooted in anarchist thinking. And, though none of its ingredients were actually original, it was Howard's remarkable contribution to assemble ideas that at the time were flourishing in various disciplinary fields, and join them in a coherent master-model, which he then communicated in easily comprehensible ways. His concept was based on a simple analysis of the urban and the rural sphere, metaphorical addressed as 'magnets' (Fig. 3). The core message of the model - following anarchist Peter Alexander Kropotkin's ideas - was the 'integration' of the urban and rural magnet - spatially, socially, economically, and culturally - in a conceptual new social space: the 'town-country' magnet. Howard created the three magnets visualization in order to make the essence of his model more easily graspable: the open form of the magnets above represented the ambivalence of positive and negative characteristics of either town or country. The magnet below collected the advantages of both complementary spheres within the new 'town-country.' Beneath the U-shape form of the magnet he put the final words: FREEDOM and CO-OPERATION, so as to summing up the social, vibrant, just, and healthy qualities of the town-country magnet. This forms the

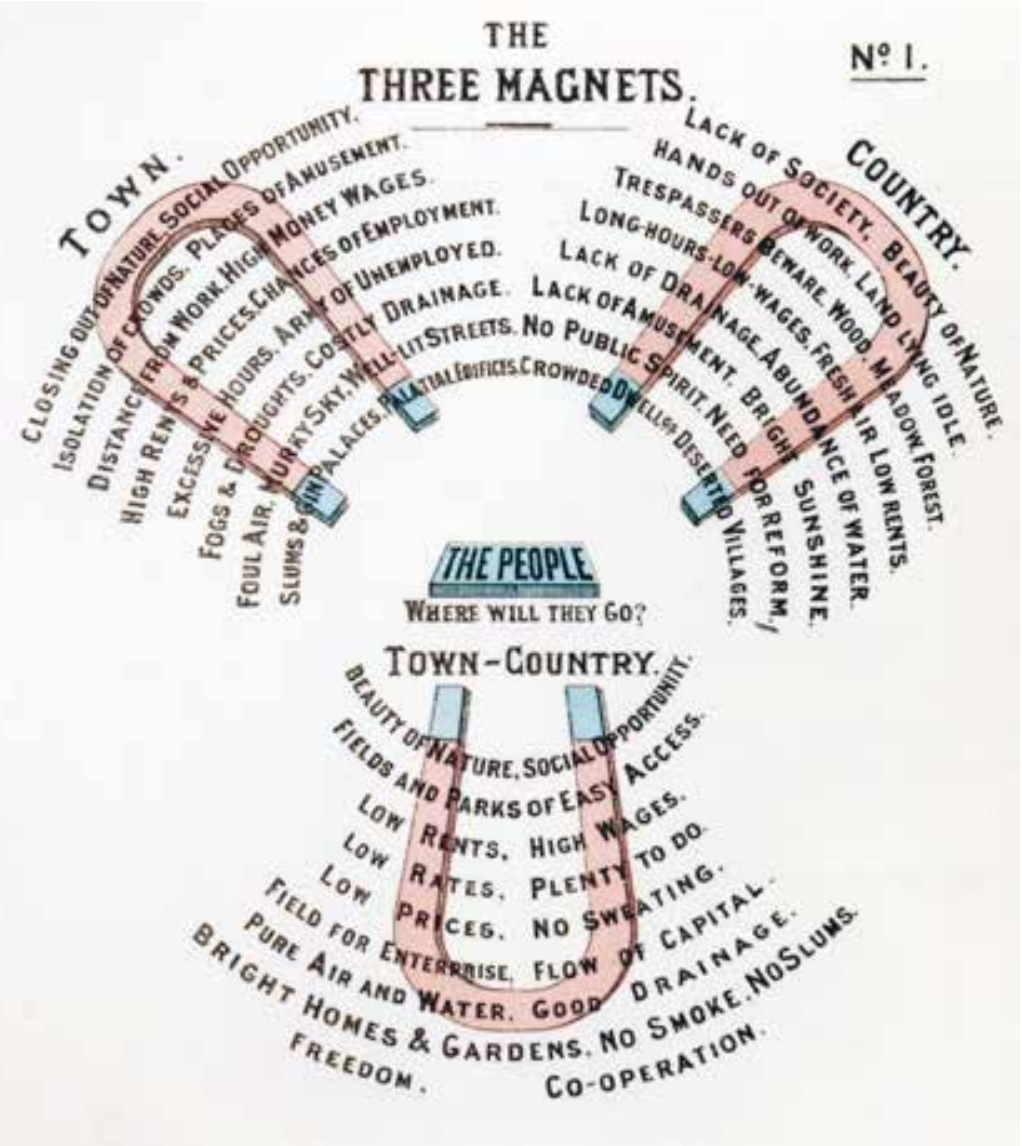

Fig. 3 Ebenezer Howard (1898), Three Magnets Model. From Ebenezer Howard, To-Morrow. A Peaceful Path for Real Reform, London: Swan Sonnenschein 1898, Diagram 1. 
Fig. 4 Ebenezer Howard (1898), Social Cities Model. From Ebenezer Howard, To-Morrow. A Peaceful Path for Real Reform, London: Swan Sonnenschein 1898, Diagram 7.

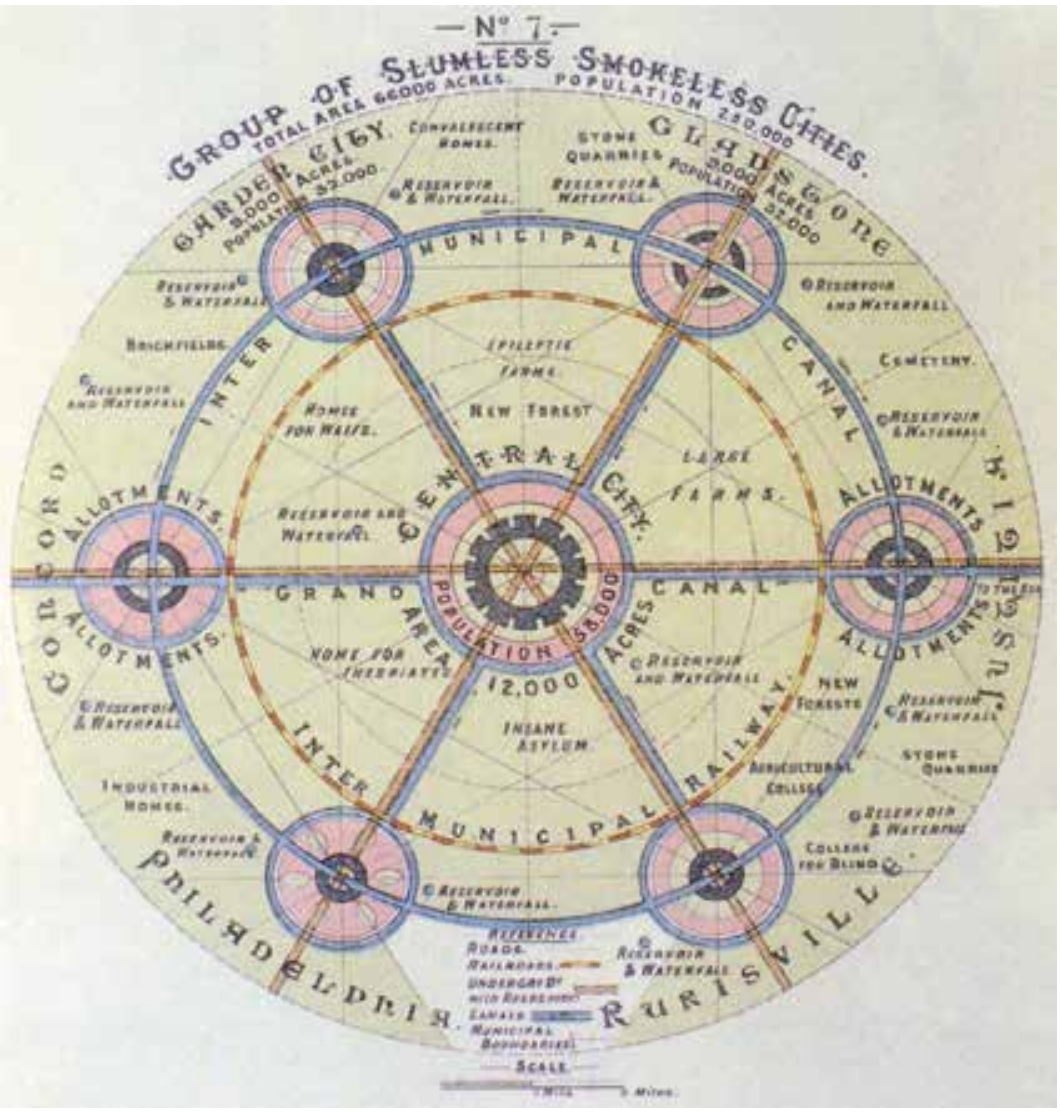

conceptual basis of Howard's idea of the Social Cities, synonym of Garden City (Fig. 4).

Howard's model of Social Cities consists of three core elements that refer to three fields of action in urban development conventionally related to urban or rural contexts (Hall, Hardy \& Colin, 2003, p. 44).

- co-operating commonwealths: creating communities of manageable size (rural context)

- regional production cycles (rural context)

- three-pillar model of generating land ownership (urban capitalist economy)

The Garden City model became exceptionally successful, and exactly herein lay a particular problem as the original concept was misinterpreted in manifold ways: in the beginning of the twentieth century Howards Garden City model became prominently discussed at international conferences such as the RIBA Town Planning Conference 1910. Already at the London conference the concept was more likely reduced to the planning and building of suburban settlements or as planning tool for satellite town extensions. The spatial and conceptual openness of the model, its potential to introduce more democratic and just urban development processes, to secure public participation, as well as to manage ecologic sustainability were soon falling in oblivion. 
Concepts of cities' development and forms of professional communication changed distinctly after World War I. The War had deeply unsettled the conception of the Western liberal economic civil societies and had shattered their economic, political, and cultural foundations, which had all been important premises of the nineteenthcentury urbanization processes. The resulting fundamental political destabilization and economic and social changes throughout Europe led to democratic and communist experiments in a number of countries, as well as to totalitarian government structures.

It seemed that the distortions of the war had cut the connection to the past. Younger actors in the field searched for systems of new order and values. Entitled The Dissolution of the Cities or The Earth, a good Shelter, Bruno Taut published his visions of new cities and settlements embedded into river and mountain landscapes. The extreme lack of housing stimulated the search for fundamentally new forms of settlement. Comprehensive visions of functionally and socially structured new towns, organic city models - apparently on the basis of Ebenezer Howard's idea of the Garden City - became the prevailing trend in city and regional planning in Europe and the USA. The periphery was its target area.

This aspiration in architecture and city planning aligned with the prevailing critique of the social and hygienic problems that arose from the dense and compact corpus of the historic city. It united the actors in the field and created their principal aim: to dissolve the solid physical, social and mental formation of the nineteenth-century city and integrate it into nature - or even as nature. Periphery played the primary part, seen as virgin soil, near to nature, and seemingly free of physical or historic signs of the urban. Already in the early 1920s, young German-speaking city planners like Paul Wolf (1919), Karl August Hoepfner (1921), and Otto Blum (1921) published new handbooks on town planning, outlining the functional and spatial structure of the decentralized city, the city as an organism, and as a system of connections between center and periphery. Howard's Garden City became the reference and the most important predecessor of these fresh approaches towards an organic city or the urban landscape. The will to create radically anew in line with nature provided these cybernetic systems with supra-personal authority.

However, the conceptional plurality and the open-minded international exchange in town planning at the beginning of the century were rigidly replaced by the hegemony of the 'urbanregionalists' perspective.

Since the early 1930 s the modernist planning paradigm gained stature. It was as well incorporated into official town planning and state bureaucracy as it was absorbed by NS-ideology and further developed in the cybernatic urban and regional planning systems (Figs. 5, 6) as created by Gottfried Feder and Walther Christaller (Feder 1939, Christaller 1933). And it was spread internationally by efficiently 
Fig. 5 Gottfried Feder (1939), Die neue Stadt. Cybernetic system of mass production of traditional towns. From Gottfried Feder, Die neue Stadt, Berlin: Springer, 1939, p. 48.

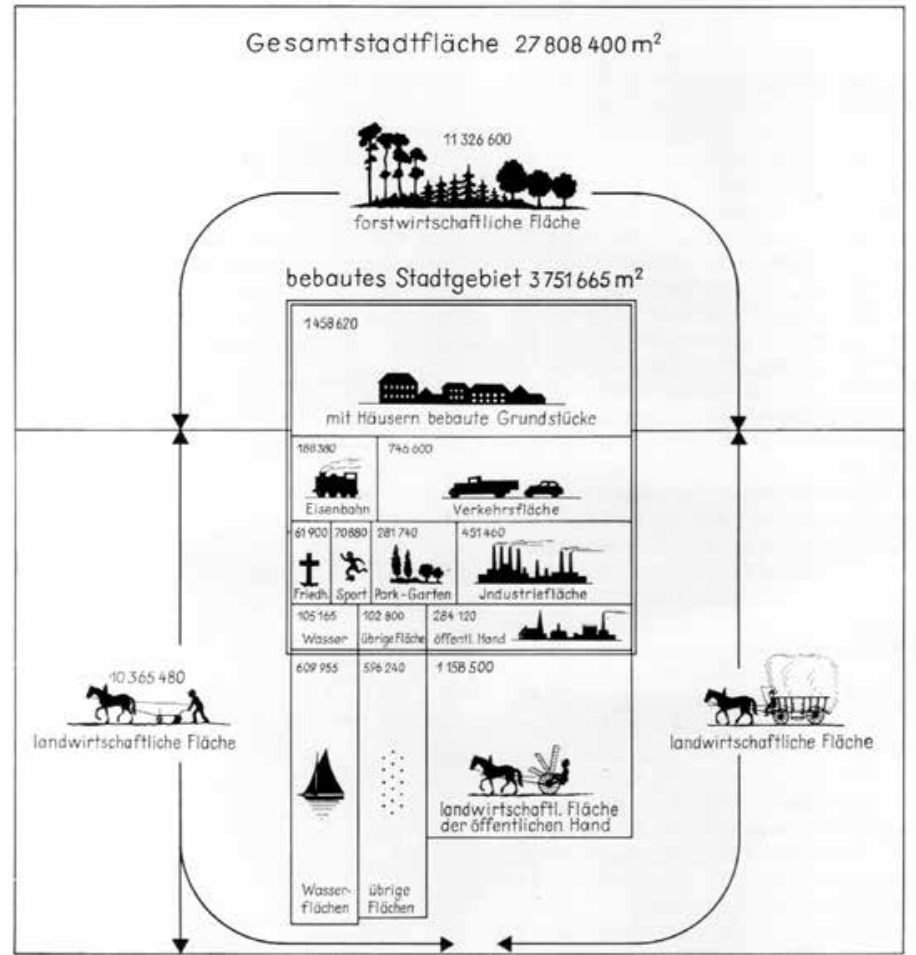

Fig. 6 Walther Christaller (1933), Christaller hypothesis: the central places model From Walther Christaller, Die zentralen Orte in Süddeutschland, Jena 1933. Graphic: BEST Berlin, 2015.

Fig. 7 The New Urban Rural Connectivity (Kress 2016). From Graphic: BEST, Berlin 2016.
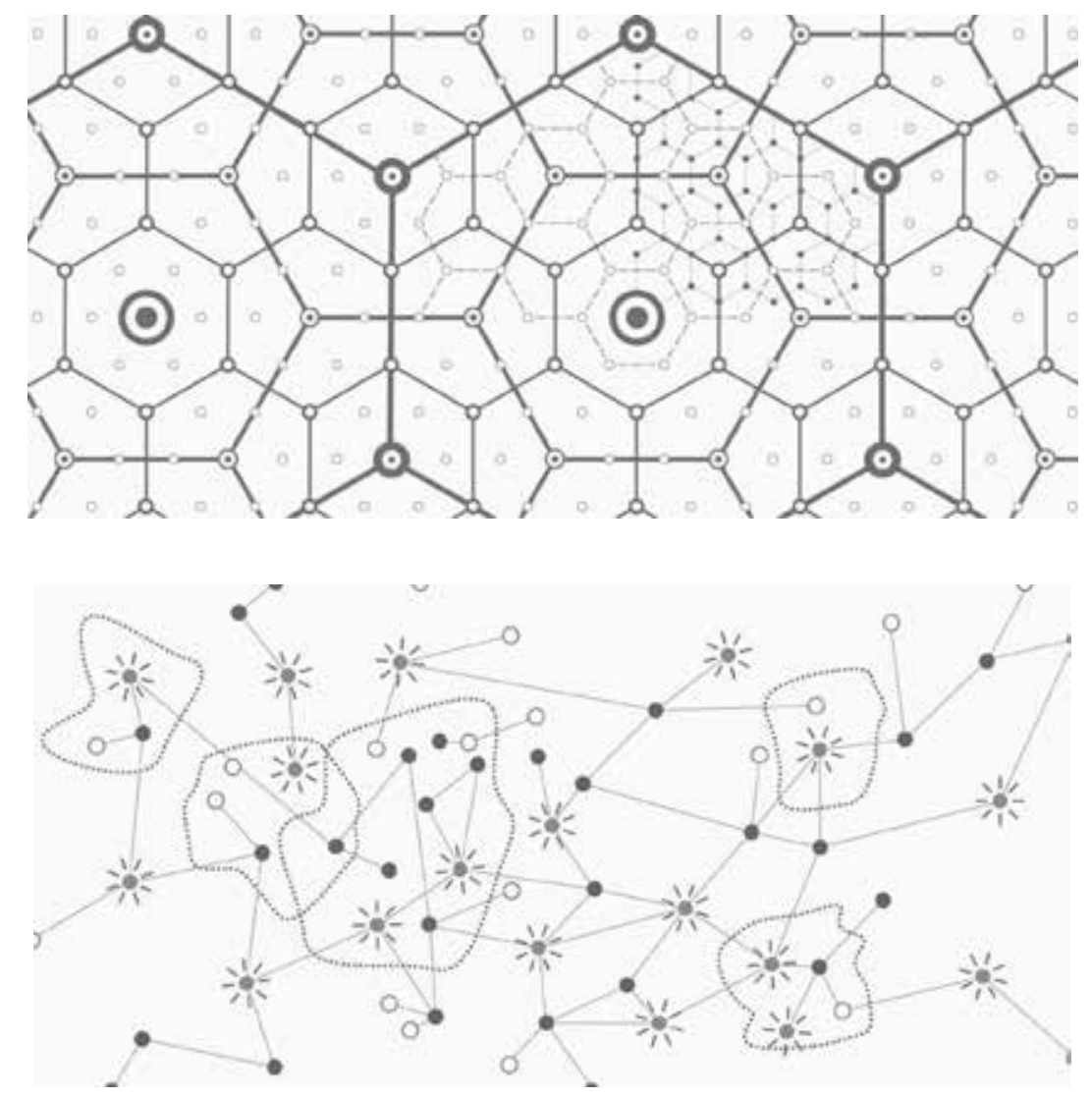
working international experts' networks such as the CIAM (Congrès Internationaux d'Architecture Moderne). The decentralized and functionally segregated city became the prevalent aim of town planning and urban renewal practices in Europe and North America since the CIAM proclaimed the Athens's charter at its fourth meeting on a cruiseship bound for Athens from Marseilles in 1933. These principles became most rigidly adapted in city planning after World War II. It seemed adequate and possible then to rebuild the European cities from the scratch. The peculiar social, political and economic conditions of the postwar times help to explain the long-term persistence of the functionalist planning paradigm up into the 1970s (Düwel \& Gutschow, 2003).

\section{Return to the City: Revaluation or Overvaluation of the Urban?}

Beginning in the 1950s, the critique of this paradigm began to flourish involving many disciplinary perspectives and fields of action. Enormous artistic, political and scholarly efforts were applied and contestation lasted for decades until such aspects of urban thought and planning as had been advocated by the 'urbanists' perspective' already prior to the First World War were finally recovered in the beginning of the twenty-first century. In order to understand the fierceness of this battle the nature of the prevailing modernist planning paradigm has to be fully grasped. This means to recognize the critical coincidence of three aspects: the organic city model that was neatly connected with the belief in the efficiency of spatial planning and with the deployment of authoritarian governance structures during the twentieth century.

Since the 1950s, a growing amount of criticism was primarily raised by intellectuals and actors of the avant-garde. They did not internationally form a solid group or a fixed network, but worked in national and city-centred circles. Their communication media developed within a growing field of new, spontaneous publishers, posters, flyers and fanzines. Contacts and exchange flourished on a personal level. They worked in various disciplinary fields and attacked modernist city planning from manifold perspectives. Influential initiatives were active in larger European cities; in Paris: Guy Debord and Asger Jorn with the International Situationists; in London: the activists and architects Cedric Price, together with the 'Non-Plan colleagues' Reyner Banham, Paul Barker and Peter Hall, team ten and Archigram; in the USA: the architects Robert Venturi and Denise Scott Brown, Kevin Lynch and Christopher Alexander; in Italy: morphologists and typologists such as Saverio Muratori and Aldo Rossi, in line with Rob and Leon Krier and O. M. Ungers in Germany (Figs. 8, 9). They expressed their critique through performative action, art, and analytical architecture, arguing for 'legibility,' 'physical experience,' 'historic rootedness.' Other actors criticized the results of modern planning and the actual physical and social condition of the cities more explicitly, such as the German sociologist Hans Paul Bahrdt, Edgar Salin, the

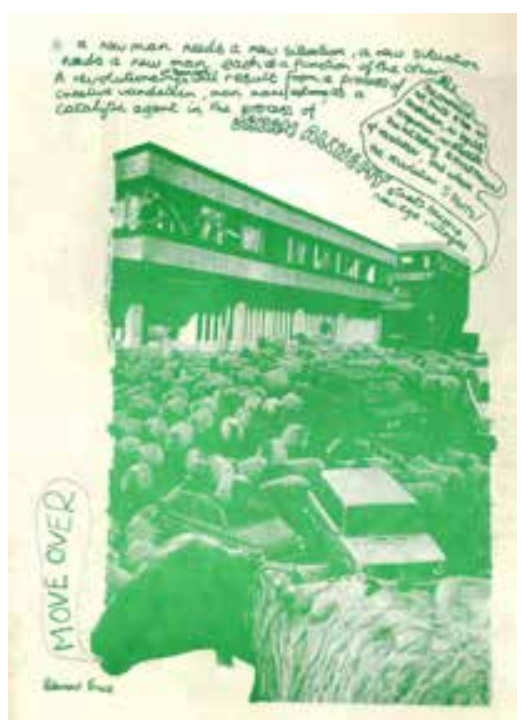

Fig. 8 Street Farmer Issue, no. 2, 1972.

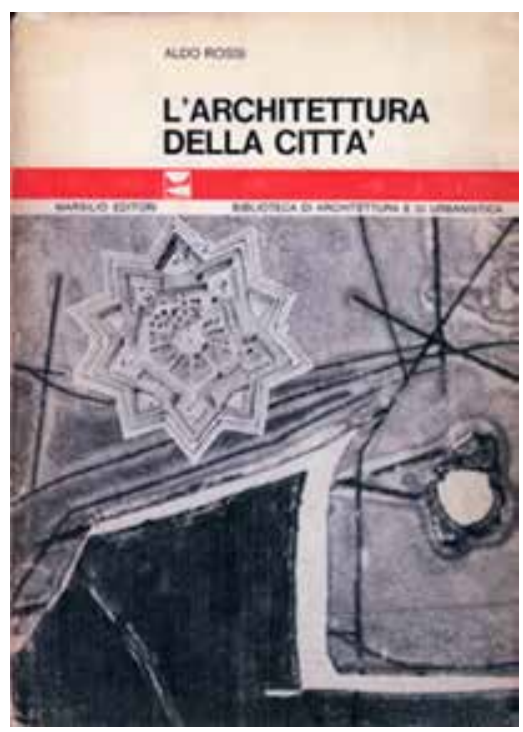

Fig. 9 Aldo Rossi (1966) L'Architettura della Città, Marsilio book cover. 
Marxist sociologist Henri Lefebvre in Paris, and the political journalist and urban activist Jane Jacobs in New York.

All of them aimed at newly introducing and securing the common awareness of specificities, ambivalences and even contradictions in the nature, and the social, political, and cultural formation of spatial configurations, such as regional landscapes and cities. However, it was the urban perspective that gained dominance over the rural during the following decades. A most important scope of artistic and political action was the rehabilitation of the physical structure of old cities aiming at protecting them from destruction in the name of urban renewal. In this fierce battle 'urbanism' (Urbanität) became the keyword. Scholars, planners and urban activists intentionally connected the term exactly with those conditions that they conceptually intended, such as social and functional mixture or participation. Likewise the term expressed the radical rejection of the then still prevailing modernist principles as there were urban landscapes and suburban lifestyles.

With this strategic aim the Marxist philosopher Henri Lefebvre (2003) developed his theory of "complete urbanization" and proclaimed an impending situation of "implosion-explosion," defining this as the "rural exodus" and "complete subordination of the rural to the urban." Lefebvre argued from the historic perspective of the functionalist prefigured reality of city planning during the 1950 s and 1960s. While he intended to strengthen the urban realm and find an adequate theory for ongoing processes of spatial, social, and economic restructuring, he indeed stigmatized 'the rural.' With his militant prophecy all 'other' spaces - including (urban) landscapes, the periphery, brownfields etc. were put on the defensive.

From the perspective of the present time, it becomes clear that in order to replace the prevailing functionalist planning paradigm, the growing critique had to create a strong counter-model, which had to be mediated within the planning sector. The choice was made for an uncompromising united campaign for the revaluation of the city and the urban, aiming at a 'reconquest of the historic city.' The efforts made by a growing number of experts in the field during the following years caused the adoption of several protective measures for the historic city centers (e.g. Venice Charter 1964, and European Architectural Heritage Year 1975), and led to a remarkable change from the practice of urban renewal as demolition practice to new ways of gentle urban regeneration in European and the US city centers. From the mid 1970s on, urban planners directed their emotional interest to a considerable extent towards the cities' core areas. Now architects and planners praised the urban qualities of the cities' centres with a similarly certain conviction as they had opted for neighborhood qualities at the periphery during the decades before.

However, reality was not as clear as it may seem at a glance: while the historic centres were saved from removal their neighbourhoods 
became threatened by gentrification - And at the urban fringes urban planners had no remedies against suburbia and sprawl.

Since the 1980s these dynamically growing areas between the urban and the rural space became more and more interesting objects of scholarly research mainly in Europe and in the USA.

\section{Uncertainty, the New Urban-Rural Connectivity, and the Garden City Model}

With his book Reassembling the Social: Introduction to the ActorNetwork-Theory in 2005, Bruno Latour firstly proposed the concept of 'uncertainty' as to address new topographies of the social. 'Uncertainty' then was rapidly adopted by the spatial sciences and planning disciplines as to describe new spatial qualities - mainly at the urban fringes and between cities.

Publications such as "La città diffusa" (Indovina, 1990), "Zwischenstadt" (Sieverts, 1997), and "La ciudad dispersa" (Monclús, 1998) directed the analytical conception towards the intermediate and peripheral zones of and between the urban cores.

In the United States scholars of the Los Angeles School conceptualized the complex urbanization patterns and dynamics of the expanding, functionally increasingly divers metropolitan regions and harshly criticized the urban centre-focussed approach of the Chicago school (Soja, 2000; Dear, 2002). Since the 1990s a variety of concepts and new terms were proposed for new 'uncertain' urban spatial settings (Fig. 10) such as "Generic City" (Koolhaas \& Mau, 1995, pp. 12381268), "Edge City" (Garreau, 1991), or the "Endless City" (Burdett \& Sudjic, 2007).

More recently the IBA Hamburg started working on the 'inner peripheries,' termed as 'Metrozones' (Hellweg , 2010) as similarly did the Pre-IBA team for a provisioned IBA Berlin 2020 looking for 'voids' in the urban tissue (IBA Berlin, 2016).

In the above mentioned planning or research contexts "uncertain spaces' are commonly addressed as "urbanized landscape". We argue here, that the conceptual incorporation into an enlarged urban paradigm does neither seem adequate nor too effective. Thus we propose to rather uncover and strengthen their specialities - as they offer a complementary arsenal for a productive cooperation between the urban and the rural. As to systematically examine the positive potentials of these zones and to make them available for further urban and regional development a new theoretical approach is needed.

Franz Oswald und Peter Baccini (2003) have introduced the concept of "network city" (Netzstadt) into the urban design and planning sciences. It should figure as a structural model of the urban space based on relations and exchange processes between various types and formations of actors, as a planning method and as a strategy within participatory planning processes.

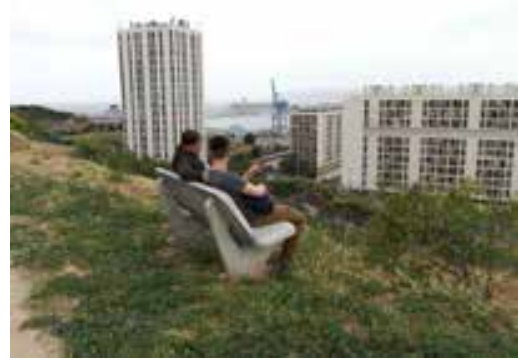

Fig. 10 Marseille nord, GR_2013. Grande Randonée walking tour testing uncertain spaces. From Foto: BEST Berlin, 2014. 


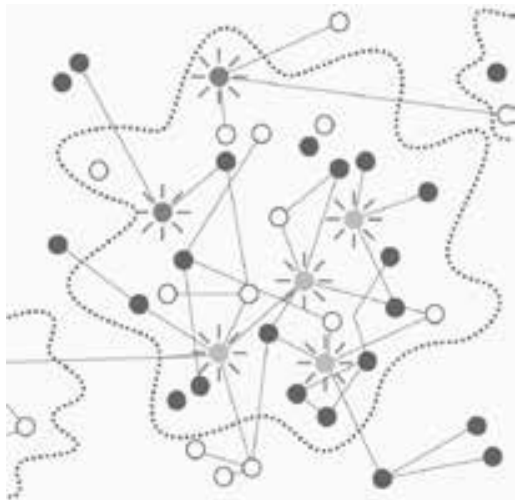

Fig. 11 Amalgam City (Frey 2006). From Graphic: BEST, Berlin 2016, re-design of Oliver Frey 2006.

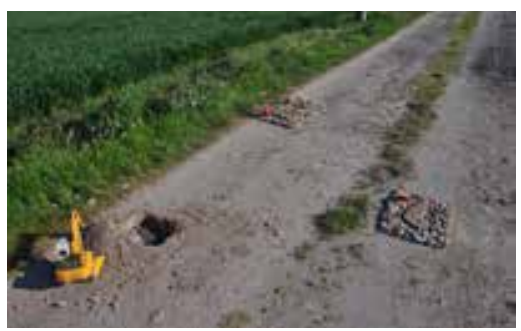

Fig. 12 Urban rural items, 2016. Installation by Gert Hein de Visser, artist from Amsterdam, living and working in the Oderbruch, a landscape at the east end of Germany. From Installation by Gert Hein de Visser , Foto: BEST Berlin, 2016.
Oliver Frey's model of the Amalgam City (Frey, 2006) attempts to display the simultaneity of the dissolution and the reinforcing of urban development patterns by means of new processes of identity-building. It clearly includes specific spatial-historical facts and emphazises multifold entanglements and interaction of the built spaces, identitycreating forces, and social networks, as for example 'urban scenes' (Fig. 11).

The Network City and Amalgam City model are both actors orientated, relational, and they describe cities as open structures. However, both models reclaim potentials of innovation and originality mainly for the cities, respectively for the urbane.

During the early 1990s the German sociologist Detlev Ipsen tried to introduce a new historically based perspective regarding the rural. Ipsen (1992) raised three examples for the meaningful creative force of the rural: He described (1) the urban-rural co-existences as "structural dualism" of urbanization in the nineteenth century, (2) the rural space as important target of the Fordistic market, and (3) envisioned that specific rural expertises, such as economic multitasking or traditional rural-manufactoral skills, might raise a new attention to facing the challenges of global transformation and new regulation systems (Fig. 12).

This is the point of departure for our concept of a new Urban-Rural Connectivity or the new Urban-Rural Space ${ }^{5}$ which may help to newly conceive a space of equal encounter, exchange and co-operation of the urban and the rural (fig. 7).

The new Urban-Rural Connectivity is based on and produced by social-material interaction (co-operation). The scheme relocates the image section towards the countryside. Connecting lines represent multidimensional actor networks following Latour's definition of the term (Latour 2005, pp. 128-130).

Coming back to the potentials of the Garden City model: anarchist imagination always referred to the planetary territory while incorporating urban and rural phenomena and treating them relationally. We propose to adopt this thinking as to establish a model which helps in describing and explaining the multifold entangled social, cultural, and territorial dynamics of the urban-rural spaces of the twentieth and twenty-first centuries. The new Urban-Rural Space will connect both ends at eye-level. Moreover, new Urban-Rural Connectivity aims at (1) providing an adequate analytical framework (2) procuring visions or ideas for the 'good city' and (3) combining it with action. And once again, for this approach the Garden City model, as one of the most prominent modernist utopias, offers some compelling suggestions. 
$1 \rightarrow$ As further sources for "a fuller account" of orthodox modern city planning she raised: The Culture of Cities (1938), by Lewis Mumford; Cities in Evolution (1915), by Sir Patrick Geddes; Modern Housing (1934), by Catherine Bauer; Toward New Towns for America (1951), by Clarence Stein; Nothing Gained by Overcrowding (1912), by Sir Raymond Unwin; The City of Tomorrow and Its Planning (1929), by Le Corbusier.

$2 \rightarrow$ In this chapter Jacobs unfolds her interpretation of the results of archeologic excavations at Çatal Hüyük/Turkey which were executed during the 1960s. Archeologists assumed that they had found a huge settlement, probably a city of around 10.000 inhabitants, as early as 7.500 b.c.

$3 \rightarrow$ E. g. see (Tönnies, 1887).

$4 \rightarrow$ Howard even more specifically proposed the construction of huge planned polycentric urban agglomerations as indicated in a diagram entitled Social Cities (see Fig. 4), which was lost in further editions of the text, as Peter Hall mentioned. See for example: (Hall, Hardy \& Colin, 2003, p. III).

$5 \rightarrow$ The term was firstly used for a new participation-oriented spatial communication format "Stadt-Land gestalten" (Shaping the Urban-Rural Space) of the Brandenburg Chamber of Architects in 2015. See https://WwW.ak-brandenburg.de/ content/stadt-land-gestalten-mach-mit, retrieved 9 October 2016. Cf. (Bröcker, Kress \& Oelker, 2015).

\section{References}

Blum, O. (1921). Städtebau, Berlin: Springer.

-

Bröcker, N, Kress, C \& Oelker, S. (2015). Stadt-Land gestalten 01: Garten / Stadt Plaue. Potsdam: bud.

-

Burdett, R. \& Sudjic, D. (2007). The Endless City. London: Phaidon.

Christaller, W. (1933) Die zentralen Orte in Süddeutschland, Jena: Fischer.

$-$

Dear, M. (2002). Los Angeles and the Chicago School: Invitation to a Debate. City and Community 1 (1), pp. 5-32.

$-$

Düwel, J. \& Gutschow, N. (2003). A Blessing in

Disguise. War and Town Planning in Europe 19401945. Berlin: DOM Publishers.

-

Feder, G. (1939) Die neue Stadt, Berlin: Springer.

Frey, O. (2006, September 15). Ein neuer Stadttypus in der Wissensgesellschaft: Die amalgame Stadt der kreativen Milieus. H-Soz-Kult. Retrieved 28 September 2016, from http://www.hsozkult.de/ debate/id/diskussionen-795.

Garreau, J. (1991). Edge City. Life on the New Frontier. New York: Doubleday.
Hall, P. (1988). Cities of Tomorrow. Oxford: Blackwell

-

Hall, P., Hardy, D. \& Ward, C. (Eds.). (2003).

Ebenezer Howard. To-morrow. A Peaceful Path to Real Reform. New York: Routledge.

Hellweg, Uli, IBA Hamburg (Ed.). (2010). Metropole: Metrozonen (vol. 4). Berlin: Jovis.

-

Hoepfner, K. A. (1921). Grundbegriffe des

Städtebaues, Berlin: Springer.

$-$

IBA Berlin 2020 / Senatsverwaltung für Stadtentwicklung und Umwelt - Berlin. (2016). Stadtentwicklung.berlin.de. Retrieved 9 October 2016, from http://www.stadtentwicklung.berlin.de/ staedtebau/baukultur/iba/index.shtml

-

Indovina, F. (1990). La città diffusa. Venice: Daest, Venice.

-

Ipsen, D. (1992). Stadt und Land - Metamorphosen einer Beziehung, In Stadt und Raum. Soziologische Analysen, edited by Hartmut Häußermann e.a., Pfaffenweiler: Centaurus, 119-120.

Jacobs, J. (1961). The Death and Life of Great American Cities. New York: Vintage Books, Random House.
Jacobs, J. (1969). The Economy of Cities. New York: Random House.

-

Koolhaas, R. \& Mau, B. (1995). S,M,L,XL. New York: Monacelli.

Latour, B. (2005) Latour, Bruno. Reassembling the Social. An Introduction to Actor-Network-Theory. Oxford: Oxford University Press.

Lefebvre, H. (2003). The Urban Revolution. Minneapolis: University of Minnesota Press.

Monclús, J. F. (Ed.). (1998). La ciudad dispersa. Barcelona: Centro de Cultura Contemporània de Barcelona.

Oswald, F \& Baccini, P. (2003). Netzstadt. Einführung in das Stadtentwerfen. Basel e.a.: Birkhäuser.

Sieverts, T. (1997). Zwischenstadt. Braunschweig e.a.: Vieweg.

-

Soja, E. W. (2000). Postmetropolis. Critical Studies of Cities and Regions. Oxford: Blackwell.

Tönnies, F. (1887). Gemeinschaft und Gesellschaft. Leipzig: Fues.

Wolf, P. (1919). Städtebau. Das Formproblem der Stadt in Vergangenheit und Zukunft. Leipzig: Klinkhardt and Biermann. 